\title{
Papers
}

\section{Clinical application of the Quantiplex HCV RNA 2.0 and Amplicor HCV Monitor assays for quantifying serum hepatitis $\mathrm{C}$ virus $\mathrm{RNA}$}

Ming-Lung Yu, Wan-Long Chuang, Shinn-Cherng Chen, Zu-Yau Lin, Ming-Yuh Hsieh, Liang-Yen Wang, Wen-Yu Chang

\begin{abstract}
Aim-To compare the performance characteristics and clinical application of two different technologies for quantifying serum hepatitis $\mathrm{C}$ virus (HCV) RNA levels.

Methods-HCV RNA was quantified by Amplicor HCV Monitor assay (Amplicor) and Quantiplex HCV RNA 2.0 assay (bDNA-2) in 119 sera from $107 \mathrm{HCV}$ infected patients.

Results-Both assays had similar sensitivity $\mathbf{7 9 . 4 \%}$ for Amplicor; $\mathbf{8 6 . 0 \%}$ for bDNA2 ), acceptable coefficients of variation (5.3\% in Amplicor; $2.6 \%$ in bDNA-2), and good linearity $\left(r^{2} \geqslant 0.98\right)$. There was a positive correlation between quantification values of both methods $(r=\mathbf{0 . 6 8 3}$, p < 0.001). The Amplicor values were on an average $1.76 \mathrm{log}$ lower than bDNA-2 results. Male subjects and $\mathrm{HCV}$ genotype 1b were significantly associated with higher viral load determined by Amplicor, but not with viral load measured by bDNA-2. In 70 chronic $\mathrm{HCV}$ infected patients treated with interferon alfa, mean (SD) pretreatment viral load in 27 complete responders $(3.47 \quad(0.84)$ logs for Amplicor, 5.63 (0.58) for bDNA-2) was significantly lower than in non-responders (4.43 (1.01) logs for Amplicor, 6.10 (0.67) logs for bDNA-2; $p<0.001$ ). Cut off points of $3.9 \mathrm{logs}$ for Amplicor and $5.8 \mathrm{logs}$ for bDNA-2 were determined to be the best for predicting response to interferon alfa,

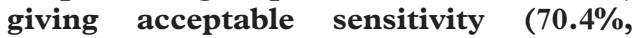
$74.1 \%)$, specificity $(72.1 \%, 65.1 \%)$, and accuracy $(71.4 \%, 68.6 \%)$, respectively. Conclusions-Both the Amplicor and bDNA-2 assays are clinically useful methods for HCV RNA quantification and are reliable for predicting the outcome of treatment, despite differences in absolute quantification values and in the correlation between HCV genotypes and viral load.

(f Clin Pathol 1999;52:807-811)
\end{abstract}

Keywords: hepatitis $\mathrm{C}$ virus; virus quantification assay; interferon
Hepatitis C virus (HCV), a highly heterogeneous, single stranded RNA virus, is the major aetiological agent in parenterally transmitted non-A, non-B hepatitis and often causes persistent infection leading to chronic liver disease and primary hepatocellular carcinoma. ${ }^{1-3}$ Serum HCV RNA (viral load) may correlate with the clinical stage of disease ${ }^{4}$ and HCV genotype. ${ }^{5}$ A low HCV viral load has also been observed to be one of the important predictive markers of successful treatment with interferon alfa. ${ }^{6-8}$ Assays for serum HCV RNA quantification should therefore be accurate and reproducible to permit careful clinical assessment of different HCV patient populations. Competitive reverse transcription polymerase chain reaction (RT-PCR) is useful for evaluating the state of viral replication. ${ }^{45}$ However, the method is costly, time consuming, and technically challenging, as reflected by large variations in sensitivity among different laboratories. Two commercial assays for HCV RNA quantification have become available and are widely used: the branched DNA assay (Chiron Corporation, Emeryville, California, USA) and the Amplicor HCV Monitor assay (Roche, Nutley, New Jersey, USA). ${ }^{9}{ }^{10}$ There are relatively few studies comparing the current version of bDNA assay ${ }^{11}$ (Quantiplex $\mathrm{HCV}$ RNA 2.0; bDNA-2) and the original version of the Amplicor assay, particularly in assessing

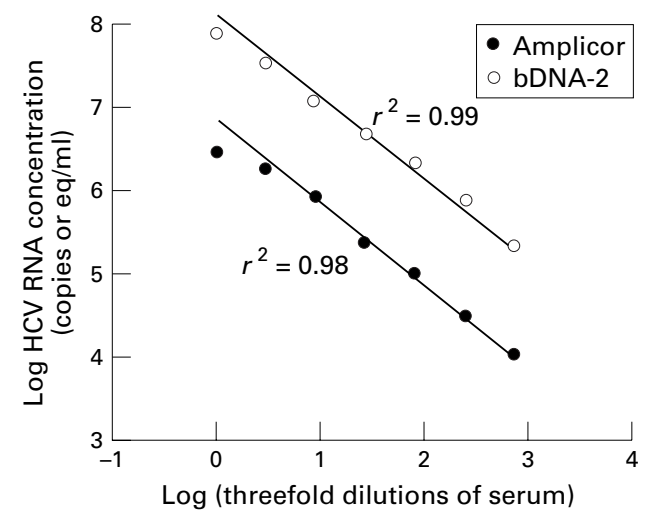

Figure 1 Analysis of HCV RNA in serial dilutions of high titre serum by two different quantitative assays, the Quantiplex branched-DNA $2.0(b D N A-2)$ assay and the Roche Amplicor HCV Monitor assay. 
Table 1 Correlation between HCV genotypes and quantification values by the Amplicor and $b D N A-2$ assays

\begin{tabular}{|c|c|c|c|c|c|}
\hline \multirow[b]{2}{*}{ Genotype } & \multirow[b]{2}{*}{ No } & \multicolumn{2}{|c|}{ HCV RNA concentration * } & \multirow{2}{*}{$\begin{array}{l}\text { Spearman's rank } \\
\text { correlation coefficient }\end{array}$} & \multirow[b]{2}{*}{$p$ Value } \\
\hline & & Amplicor & $b D N A-2$ & & \\
\hline All types & 119 & $4.16(1.09)$ & $5.93(0.69)$ & 0.683 & $<0.001$ \\
\hline $1 b$ & 40 & $4.81(0.99)$ & $5.99(0.73)$ & 0.843 & $<0.001$ \\
\hline $2 \mathrm{a}$ & 46 & $3.77(0.87)$ & $6.06(0.63)$ & 0.784 & $<0.001$ \\
\hline $2 \mathrm{~b}$ & 7 & $4.15(1.57)$ & $5.88(1.05)$ & 0.785 & $<0.05$ \\
\hline $3 \mathrm{a}$ & 1 & 4.11 & 5.46 & & \\
\hline Mixed & 9 & $3.60(1.06)$ & $5.78(0.57)$ & 0.801 & 0.01 \\
\hline Unclassified & 16 & $3.95(1.07)$ & $5.57(0.53)$ & 0.758 & 0.001 \\
\hline
\end{tabular}

^ Expressed as mean (SD) of logarithmic transformation (log copy or equivalent/ml).

Table 2 Background of HCV infected patients and their serum HCV RNA levels measured by the Amplicor and bDNA-2 assays

\begin{tabular}{|c|c|c|c|}
\hline Characteristics & No & Amplicor* & $b D N A-2^{\star}$ \\
\hline All patients & 107 & $4.17(1.10)$ & $5.93(0.65)$ \\
\hline \multicolumn{4}{|l|}{ Age (years) } \\
\hline Below 40 & 32 & $4.03(1.09)$ & $5.88(0.65)$ \\
\hline 40 to 60 & 54 & $4.34(1.07)$ & $5.97(0.64)$ \\
\hline Above 60 & 21 & $3.96(1.18)$ & $5.92\left(\begin{array}{l}0 \\
0\end{array}\right.$ \\
\hline \multicolumn{4}{|l|}{ Sex } \\
\hline Male & 59 & $4.40(1.08) \dagger$ & $6.03(0.61)$ \\
\hline Female & 48 & $3.90(1.07) \dagger$ & $5.82(0.68)$ \\
\hline \multicolumn{4}{|l|}{ Mode of transmission } \\
\hline Transfusion & 41 & $3.96(1.13)$ & $5.88(0.60)$ \\
\hline $\begin{array}{l}\text { Percutaneous } \\
\text { procedure }\end{array}$ & 35 & $4.20(1.07)$ & $5.93\left(\begin{array}{lll}0 & 62\end{array}\right)$ \\
\hline Unknown & 31 & $4.31(1.09)$ & $6.01\left(\begin{array}{ll}0 & 67\end{array}\right)$ \\
\hline \multicolumn{4}{|l|}{ Alanine aminotransferase } \\
\hline Normal $(\leqslant 25 \mathrm{IU} / 1)$ & 6 & $3.40(0.84)$ & $5.46(0.55)$ \\
\hline Abnormal (> $25 \mathrm{IU} / \mathrm{l})$ & 101 & $4.22(1.10)$ & $5.96(0.65)$ \\
\hline \multicolumn{4}{|l|}{ Histology } \\
\hline Acute hepatiti & 4 & $4.45(1.24)$ & $5.80(0.81)$ \\
\hline $\begin{array}{l}\text { Chronic persistent } \\
\text { hepatitis }\end{array}$ & 17 & $4.52(0.89)$ & $6.11(0.76)$ \\
\hline $\begin{array}{l}\text { Chronic active } \\
\text { hepatitis }\end{array}$ & 53 & $3.99(1.08)$ & $5.94(0.59)$ \\
\hline Liver cirrhosis & 22 & $4.28(1.16)$ & $5.91(0.58)$ \\
\hline $\begin{array}{l}\text { Hepatocellular } \\
\text { carcinoma }\end{array}$ & 11 & $4.19(1.34)$ & $5.74\left(\begin{array}{lll}0 & 86\end{array}\right)$ \\
\hline \multicolumn{4}{|l|}{ HCV subtype } \\
\hline $1 \mathrm{~b}$ & 40 & $4.81(0.99) \ddagger$ & $5.99(0.73)$ \\
\hline Non-1b & 67 & $3.79(0.98) \ddagger$ & $5.90(0.60)$ \\
\hline $2 \mathrm{a}$ & 41 & $3.72(0.86)$ & $6.05(0.58)$ \\
\hline $2 \mathrm{~b}$ & 4 & $4.45(1.58)$ & $5.92(0.91)$ \\
\hline $3 a$ & 1 & 4.11 & 5.46 \\
\hline Unclassifie & 12 & $3.94(1.17)$ & $5.54(0.50)$ \\
\hline Mixed infection & 9 & $3.60(1.06)$ & $5.78(0.57)$ \\
\hline
\end{tabular}

* Mean (SD) deviation of logarithmic transformation of log copies or equivalents $/ \mathrm{ml}$

†Probability of difference in sex and viral load by the Amplicor assay $(\mathrm{p}<0.05)$.

¥Probability of differences in HCV genotypes and viral load by the Amplicor assay $(\mathrm{p}<0.001)$.

their ability to predict response to interferon alfa treatment in patients with chronic hepatitis C. Objectives of the current study were: (1) to compare the clinical sensitivity, reproducibility, linearity, and correlation of the Amplicor and bDNA-2 assays in patients of different $\mathrm{HCV}$ genotypes and stages of infection; and (2) to

Table 3 Stepwise multiple linear regression analysis of factors associated with serum HCV RNA levels

\begin{tabular}{|c|c|c|c|c|}
\hline Assay variables & Coefficients & $\begin{array}{l}\text { Standard error } \\
\text { of coefficient }\end{array}$ & $\begin{array}{l}\text { Adjusted } \\
\text { multiple } r^{2}\end{array}$ & $p$ Value \\
\hline \multicolumn{5}{|l|}{ Amplicor assay } \\
\hline / Intercept (log copies/ml) & 4.38 & & & \\
\hline$/$ Sex $($ male $=1$, female $=2)$ & 0.39 & 0.19 & 0.23 & $<0.05$ \\
\hline $\begin{array}{l}\text { / HCV genotype (genotype } 1=1, \\
\text { non-genotype } 1 \mathrm{~b}=0 \text { ) }\end{array}$ & 0.97 & 0.20 & 0.20 & $<0.01$ \\
\hline \multicolumn{5}{|l|}{ BDNA-2 assay } \\
\hline /Intercept $(\log$ eq $/ \mathrm{ml})$ & 5.93 & & & \\
\hline
\end{tabular}

Factors such as age, sex, mode of transmission, aminotransferase, histology, and HCV genotype were analysed by stepwise multiple linear regression. Males and patients infected with genotype $1 \mathrm{~b}$ virus had significantly higher HCV RNA levels, as determined with the Amplicor assay. No factors were significantly associated with viral load measured by the bDNA-2 assay. determine the clinical value of these two commercial $\mathrm{HCV}$ viral load assays for predicting response to interferon alfa treatment.

\section{Methods}

PATIENTS

One hundred and seven Taiwanese patients were enrolled in the study. Seventy patients with chronic hepatitis C were treated with 6 MU of interferon alfa given intramuscularly three times a week for 24 weeks. Complete responders were defined as patients showing normal alanine aminotransferase (ALT) levels and clearance of HCV RNA by nested RT-PCR at the end of the treatment and for six months after the cessation of treatment. All other patients were classified as nonresponders. All serum samples were positive for HCV RNA, including 107 samples collected at the time of liver biopsy or aspiration cytology for measurement of baseline viral load, and an additional 12 samples from 12 patients at the third month of interferon alfa treatment.

DETECTION/QUANTIFICATION OF SERUM HCV RNA AND GENOTYPING

HCV RNA was detected qualitatively by nested RT-PCR using 5' non-coding region (5'NCR) specific primers. ${ }^{12}$ The detection limit of the nested RT-PCR is 50 copies $/ \mathrm{ml}$. HCV genotyping was determined by method described by Okamoto et al. ${ }^{13}$ Levels of serum HCV RNA were measured with the bDNA-2 and Amplicor assays according to the manufacturer's instructions, which were followed exactly. HCV RNA was detected directly in the bDNA-2 assay by a series of probe hybridisations to boost the signal coming from each HCV RNA. The relative intensity of the signal was compared against an external standard curve, giving a quantification of $0.2-$ 120 million equivalents (Meq) $/ \mathrm{ml}$. The Amplicor assay is based on reverse transcription and amplification of $\mathrm{HCV}$ RNA with primers targeting an $x \mathrm{bp}$ region within the $5^{\prime}$ NCR of the $\mathrm{HCV}$ genome. An internal quantitation standard (an RNA molecule derived from genotype 1 sequence of the HCV) was coamplified with the HCV RNA target. Both the amplified products of the internal standard and sample RNA were serially diluted and detected by hybridization in a colorimetric assay. Results were calculated manually according to the manufacturer's instructions, giving a quantification range of $10^{3-6}$ copies/ $\mathrm{ml}$.

STATISTICAL ANALYSIS

Data are expressed as mean (SD) after logarithmic transformation of original values. The $\chi^{2}$ test, Student's $t$ test, analysis of variance, Spearman's rank correlation coefficient, simple linear regression, and stepwise multiple linear regression were used. We compared the area under the curve with the receiver operating characteristics (ROC) analysis $^{14}{ }^{15}$ and made an attempt to derive a suitable clinical cut off for each assay that would best predict the response to interferon alfa treatment. For the purpose of analysing the 


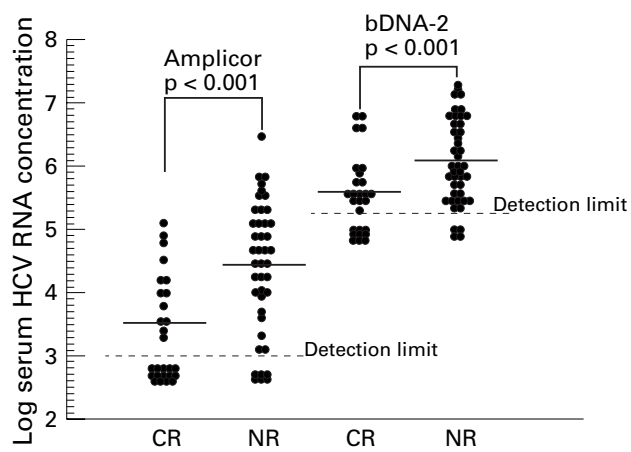

Figure 2 Pretreatment levels of serum hepatitis $C$ virus $R N A$ in responders (CR) and non-responders (NR) to interferon alfa treatment at $6 \mathrm{MU}$ thrice weekly for 24 weeks assessed by the Roche Amplicor HCV Monitor assay (Amplicor) and Quantiplex branched-DNA 2.0 assay (bDNA-2). Of 70 patients, 27 were responders. The bars represent mean pretreatment level of serum hepatitis $C$ virus $R N A$ in each group.

data by suitable statistical methods, we assigned a nominal value of $0.1 \mathrm{Meq} / \mathrm{ml}$ to samples that were negative by bDNA-2 but positive for HCV RNA by nested RT-PCR, and a nominal value of 500 copies $/ \mathrm{ml}$ to samples that were Amplicor negative but positive by nested RT-PCR.

\section{Results}

PERFORMANCE CHARACTERISTICS OF THE

AMPLICOR AND bDNA-2 ASSAYS

Of 107 samples for baseline viral load, $\mathrm{HCV}$ RNA was quantifiable in 85 patients $(79.4 \%)$ by Amplicor and in $92(86.0 \%)$ by bDNA-2. Eighty $(74.8 \%)$ samples were quantifiable by both assays, while $10(9.4 \%)$ were under the detection limit of both assays. For 12 PCR positive samples collected at the third month of interferon alfa treatment, the percentage of quantifiable samples by Amplicor and bDNA-2 was similar $(41.7 \%$ and $58.3 \%$, respectively).

To investigate assay reproducibility, each assay was tested on two occasions using different lots of reagents with separate aliquots of a

Table 4 Correlation between pretreatment levels of serum $H C V R N A$ and response to interferon alfa treatment

\begin{tabular}{|c|c|c|c|}
\hline $\begin{array}{l}\text { Pretreatment serum } \\
\text { HCV RNA level }\end{array}$ & $C R(n=27)$ & $N R(n=43)$ & p Value \\
\hline \multicolumn{4}{|c|}{ Amplicor (log copies $/ \mathrm{ml}$ ) } \\
\hline Low $(\leqslant 3)$ & $13(68.4 \%)$ & $6(31.6 \%)$ & $<0.05^{\star}$ \\
\hline Median (3-4.5) & $9(39.1 \%)$ & $14(60.9 \%)$ & \\
\hline High $(>4.5)$ & $5(17.9 \%)$ & $23(82.1 \%)$ & \\
\hline \multicolumn{4}{|l|}{$b D N A-2(\log e q / m l)$} \\
\hline Low $(\leqslant 5.3)$ & $8(66.7 \%)$ & $4(33.3 \%)$ & $<0.05^{\star}$ \\
\hline Median (5.3-6.5) & $15(38.5 \%)$ & $24(61.5 \%)$ & \\
\hline High $(>6.5)$ & $4(21.1 \%)$ & $15(78.9 \%)$ & \\
\hline
\end{tabular}

$\mathrm{CR}$, complete responder; eq, equivalent; NR, non-responder.

${ }^{\star} \chi^{2}$ test with linear correlation.

Table 5 Prediction of complete response to interferon alfa treatment based on the calculated clinical cut off values for serum HCV RNA levels

\begin{tabular}{lllll}
\hline Assays & Cut off values & Sensitivity $(n / N)$ & Specificity $(n / N)$ & Accuracy $(n / N)$ \\
\hline $\begin{array}{c}\text { Amplicor } \\
\text { (copies/ml) }\end{array}$ & $8 \times 10^{3}(3.9 \mathrm{logs})$ & $70.4 \%(19 / 27)$ & $72.1 \%(31 / 43)$ & $71.4 \%(50 / 70)$ \\
$\begin{array}{c}\text { bDNA-2 } \\
(\mathrm{eq} / \mathrm{ml})\end{array}$ & $0.65 \times 10^{6}(5.8 \mathrm{logs})$ & $74.1 \%(20 / 27)$ & $65.1 \%(28 / 43)$ & $68.6 \%(48 / 70)$ \\
\hline
\end{tabular}

Seventy patients with chronic hepatitis $\mathrm{C}$ treated with interferon alfa, $6 \mathrm{MU}$ thrice weekly for 24 weeks, were studied. The complete response rate was $38.6 \%(27 / 70)$. panel of 16 samples. The mean per cent coefficient of variation based upon repeat testing was $5.3 \%$ (range $0.8 \%$ to $10.4 \%$ ) for Amplicor and $2.6 \%$ (range $1.3 \%$ to $7.1 \%$ ) for bDNA-2. Linearity of quantification was examined with a dilution panel made by six threefold serial dilutions of a high titre serum sample into normal human sera. As shown in fig 1, both bDNA-2 and Amplicor had good linearity within the linear range $\left(r^{2}=0.99\right.$ and 0.98 , respectively).

HCV RNA quantification values measured by the Amplicor and bDNA-2 assays were positively correlated (Spearman's rank correlation coefficient, $r=0.683, \mathrm{p}<0.001)$. The Amplicor values were on average 1.76 log lower than the bDNA-2 results. Non-parametric tests of correlation gave a high correlation coefficient upon pairwise comparison of samples with different genotypes (table 1). However, the mean difference in quantification values between these two assays was $1.1 \log$ for genotype 1 and 2.1 logs for non-genotype 1 $(p<0.05)$.

HCV VIRAL LOAD AND CLINICAL MANIFESTATIONS Patient age, sex, mode of transmission, liver biochemistry, liver histology, and viral genotype were analysed to evaluate the relation between HCV viral load and clinical manifestation of HCV infection. By univariate analysis, viral load determined with Amplicor did not correlate with patient's age, mode of transmission, and severity of liver disease (table 2). HCV viral load was significantly different between male and female patients $(p<0.05)$, and among different HCV genotypes $(p<0.001)$. In further analysis using stepwise multiple linear regression, sex and HCV genotype remained as significant factors affecting serum HCV RNA levels measured by Amplicor (table 3). For the bDNA-2 quantification results, none of the factors analysed was found to be correlated with viral load by either univariate or multivariate analyses.

PRETREATMENT HCV RNA LEVELS AND RESPONSE TO INTERFERON ALFA TREATMENT

In 70 interferon alfa treated patients, pretreatment viral load in 27 complete responders (38.6\%) (3.47 (0.84) logs for Amplicor, 5.63 (0.58) for bDNA-2) was significantly lower than that in non-responders (4.43 (1.01) logs for Amplicor, 6.10 (0.67) logs for bDNA-2; $\mathrm{p}<0.001$, fig 2). There was no association between sex, age, pretreatment ALT levels, liver histology, HCV genotype, kind of interferon, or history of blood transfusion with the interferon response. After dividing patients into three groups with low, medium, and high viral load, the percentage of complete responders was observed to decrease with higher pretreatment serum HCV RNA concentrations $\left(\mathrm{p}<0.05, \chi^{2}\right.$ test with linear correlation) (table 4). In an attempt to accurately predict interferon alfa response by the pretreatment viral load, the most appropriate cut off in pretreatment HCV RNA was calculated by using the ROC analysis. In this analysis, patients with a pretreatment viral load lower than the cut off 
value would be considered as probable complete responders, while those with a viral load higher than the cut off value would be regarded as probable non-responders. Using a cut off value of 3.9 logs for Amplicor and 5.8 logs for bDNA-2, both the Amplicor and bDNA-2 assays had acceptable sensitivity $(70.5 \%$ and $74.1 \%)$, specificity $(72.1 \%$ and $65.1 \%)$, and accuracy $(71.4 \%$ and $68.6 \%)$ in predicting complete response to interferon alfa given at 6 MU thrice weekly for 24 weeks (table 5).

\section{Discussion}

Serum HCV RNA is an important predictive factor of response to interferon treatment in patients with chronic hepatitis C. ${ }^{6-8}$ Easy, reliable, standardised quantitative HCV RNA tests with good accuracy and reproducibility are therefore needed to popularise the routine use of viral load in the clinical management of $\mathrm{HCV}$ patients. We undertook this study to compare the commercially available Amplicor and bDNA-2 assays for clinical sensitivity, reproducibility, linearity of quantitation, and ability to quantify all HCV genotypes with equal sensitivity. Both assays showed good reproducibility, based on repetitive testing of a panel of 16 clinical samples in our study. The between run coefficients of variation were $5.3 \%$ and $2.6 \%$ in the Amplicor and bDNA-2 assays, respectively. This contrasts with the poor reproducibility in the Amplicor assay reported by Hawkins et al. ${ }^{16}$ Possible explanations for this discrepancy might be the small number of samples tested in the present study and in that by Hawkins, or differences in technical expertise in performing the test at various laboratories.

We observed that the Amplicor and bDNA-2 assays had similar clinical sensitivity, despite the vastly different quantification limits assigned by the manufacturers. Although quantification results by these two tests were positively correlated, the Amplicor values were $1.76 \log$ lower than the values obtained with the bDNA-2 assay. This difference could result from factors such as quantification standards of different lengths, sequences, and chemical properties. $^{1017}$

An important observation in our study was that there were discrepancies in the relation between genotypes and HCV viral load depending on the quantification method used. $\mathrm{HCV}$ genotype $1 \mathrm{~b}$ samples were shown to have significantly higher viral load than other genotypes in the Amplicor assay. No genotype dependent differences in viral load was observed for the bDNA-2 assay, consistent with previous reports, ${ }^{16}$ as well as with larger surveys of blood donors and patients when values obtained with the first generation bDNA assay were corrected for lower sensitivities for genotypes 2 and $3 .{ }^{18}{ }^{19}$ Furthermore, the mean difference in quantitation values between these two assays was $1.1 \log$ for genotype 1 and 2.1 logs for non-genotype 1 , even though the Amplicor and bDNA-2 results correlated well with each other for each of the HCV genotypes. Differences in viral load among HCV genotypes may have been caused by the absolute efficiency of HCV RNA detection rather than being a real biological phenomenon. HCV exists as a heterogeneous group of viruses sharing approximately $70 \%$ homology, and shows significant variations even in the most "conserved" regions of the HCV genome. ${ }^{20}{ }^{21}$ The Amplicor assay uses the most conserved regions of genotype $1 \mathrm{HCV}$ as target sequences for amplification and probe hybridisation. However, minor sequence variations between the genotype 1 sequences used in PCR primers and target sequences of non-genotype 1 viruses, ${ }^{20}$ and genotype specific differences in the strength of base pairings and in the secondary structure of the 5 'NCR, may interfere with primer annealing and thus lead to underestimation of viral load for non-genotype 1 samples. ${ }^{21}$

An unexpected finding in our study was that male sex was associated with significantly higher levels of HCV RNA by the Amplicor results. Similar results had been observed in dialysis patients by using competitive $\mathrm{PCR}^{22}$ and in blood donors using the corrected bDNA-1 results, ${ }^{18}$ but not in other studies. ${ }^{49}$ The lower viral load in female subjects might be caused by sex specific differences in viral replication that could not be detected by the bDNA-2 assay in the present study. On the other hand, the observation might be an opportunistically statistical bias: confounding factors could not be controlled for with multivariate analysis owing to the fact that the Amplicor assay might have genotype specific differences in detection efficiency, and that a difference in genotype distribution among male and female subjects $(42.4 \%$ male, $31.3 \%$ female for genotype 1 patients) contributed to sex specific differences in viral load.

Our study, as well as most other, ${ }^{6-8}$ documented that pretreatment HCV RNA level is one of the factors influencing the outcome of interferon alfa treatment, and may in fact be the single most important determinant. ${ }^{6}$ As it would be very useful for clinicians to be able to use a certain pretreatment viral load for gauging responsiveness to interferon therapy, we made an attempt to derive a suitable clinical cut off for each assay that would best predict the response to interferon. By using the ROC analysis, patients with an HCV viral load of less than 3.9 logs in the Amplicor assay or 5.8 logs in the bDNA-2 assay were considered likely to be complete responders to interferon given a dose of $6 \mathrm{MU}$ thrice weekly for 24 weeks. When these cut off points were used to analyse the interferon response in our treated patients retrospectively, the predictive rate was $70 \%$ with either of the two assays, suggesting that either assay could be used for routine viral load quantification to tailor treatment regimens. In patients with a high viral load who are expected to respond poorly to conventional interferon treatment, a higher dose, a longer duration of interferon treatment, or a combination of ribavirin plus interferon may be appropriate. ${ }^{23}$

CONCLUSIONS

Both the Amplicor and bDNA-2 assays are clinically useful methods for HCV RNA quan- 
tification, despite the existence of method related discrepancies in quantification values and in the correlation between HCV genotypes and viral load. Both assays are reliable for monitoring virological changes throughout the course of $\mathrm{HCV}$ infection and in selecting patients for treatment, and also may provide decision making information for future therapeutic strategies. However, the two assays cannot be used interchangeably owing to inherent differences in technology and performance characteristics. Clinicians should weigh the advantages and weaknesses of each assay in selecting one particular assay for clinical studies and patient management.

1 Choo QL, Kuo G, Weiner AJ, et al. Isolation of a cDNA clone derived from a blood-borne non-A, non-B viral hepatitis genome. Science 1989;244:359-62.

2 Kuo G, Choo QL, Alter HJ, et al. An assay for circulating antibodies to a major etiologic virus of human non-A, non-B hepatitis. Science 1989;244:362-4.

3 Alter MJ, Margolis HS, Krawczynski K, et al. The natural history of community-acquired hepatitis $\mathrm{C}$ in the United States. N Engl f Med 1992;327:1899-905.

4 Kato N, Yokosuka O, Hosoda K, et al. Quantification of hepatitis C virus by competitive reverse transcriptionhepatitis $\mathrm{C}$ virus by competitive reverse transcriptionpolymerase chain reaction: increase of the viru
advanced liver disease. Hepatology 1993;18:16-20.

5 Hayashi J, Kishihara Y, Yoshimura E, et al. Relationship of genotype to level of hepatitis $\mathrm{C}$ viremia determined by competitive polymerase chain reaction. F Infect 1995;30 235-9.

6 Hagiwara H, Hayashi N, Mita E, et al. Quantitative analysis of hepatitis $\mathrm{C}$ virus RNA in serum during interferon alfa therapy. Gastroenterology 1993;104:877-83.

7 Toyoda H, Nakano S, Kumada T, et al. Comparison of serum hepatitis $\mathrm{C}$ virus RNA concentration by branched DNA probe assay with competitive reverse transcription polymerase chain reaction as a predictor of response to interferon- $\alpha$ therapy in chronic hepatitis $C$ patients. $f$ Med Virol 1996;48:354-9.

8 Trabaud MA, Bailly F, Si-Ahmed SN, et al. Comparison of HCV RNA assays for the detection and quantification of hepatitis C virus RNA levels in serum of patients with hepatitis $\mathrm{C}$ virus RNA levels in serum of patients with
chronic hepatitis $\mathrm{C}$ treated with interferon. $\mathcal{F}$ Med Virol 1997;52:1-8.

9 Lau JYN, Davis GL, Kniffen J, et al. Significance of serum hepatitis C virus RNA levels in chronic hepatitis C. Lancet 1993;341:1501-4
10 Colucci G, Gutekunst K. Development of a quantitative PCR assay for monitoring HCV viremia levels in patients with chronic hepatitis C. $\mathcal{F}$ Viral Hepatitis 1997;4:75-8.

11 Detmer J, Lagier R, Flynn J, et al. Accurate quantification of hepatitis $\mathrm{C}$ virus (HCV) RNA from all $\mathrm{HCV}$ genotype by using branched-DNA technology. F Clin Microbiol 1996;34: 901-7.

12 Yu ML, Chuang WL, Lu SN, et al. The genotypes of hepatitis $\mathrm{C}$ virus in patients with chronic hepatitis $\mathrm{C}$ virus infection in Southern Taiwan. Kaohsiung f Med Sci 1996;12: 605-12.

13 Okamoto $\mathrm{H}$, Tokita $\mathrm{H}$, Sakamoto $\mathrm{M}$, et al. Characterization of the genomic sequence of type $\mathrm{V}$ (or $3 \mathrm{a}$ ) hepatitis $\mathrm{C}$ virus isolates and PCR primers for specific detection. 7 Gen Virol 1993;74:2385-90.

14 Hanley JA, McNeil BJ. A method of comparing the areas under receiver operating characteristic curves derived from the same cases. Radiology 1983;148:839-43.

15 Zweig MH, Campbell G. Receiver-operating characteristic (ROC) plots: a fundamental evaluation tool in clinical medicine. Clin Chem 1993;39:561-77.

16 Hawkins A, Davidson F, Simmonds P. Comparison of plasma virus loads among individuals infected with hepatitis $C$ virus (HCV) genotypes 1,2 , and 3 by Quantiplex HCV RNA assay versions 1 and 2, Roche Monitor assay, and an in-house limiting dilution method. $\mathcal{F}$ Clin Microbiol 1997;35:187-92.

17 Collins ML, Zayati C, Detmer JJ, et al. Preparation and characterization of RNA standards for use in quantitative branched DNA hybridization assays. Anal Biochem 1995; 226:120-9.

18 Smith DB, Davidson F, Yap PL, et al. Levels of hepatitis C virus in blood donors infected with different viral genotypes. F Infect Dis 1996;173:727-30.

19 Lau JYN, Davis GL, Prescott LE, et al. Distribution of hepatitis $\mathrm{C}$ virus genotypes determined by line probe assay in patients with chronic hepatitis C seen at tertiary referral centers in the United States. Ann Intern Med 1996;124: 868-76.

20 Lau JYN, Simmonds P, Urdea MS. Implications of variations of "conserved" regions of hepatitis C virus genome. Lancet 1995;346:425-6.

21 Smith DB, Mellor J, Jarvis LM, et al. Variation of hepatitis C virus $5^{\prime}$ non-coding region: implications for secondary virus 5 ' non-coding region: implications for secondary
structure, virus detection and typing. $f$ Gen Virol structure, virus

22 Dubois DB, Gretch D, Rosa CD, et al. Quantitation of hepatitis C viral RNA in sera of hemodialysis patients: gender-related differences in viral load. Am $\mathcal{F}$ Kidney Dis 1994;24:795-801.

23 Reichard O, Norkrans G, Fryden A, et al. Randomised, double-blind, placebo-controlled trial of interferon $\alpha-2 b$ with and without ribavirin for chronic hepatitis C. Lancet 1998;351:83-7. 